\section{Research Article}

\author{
C 2019 Ra'ad A. Al-Awamleh and Yusra S. Alkhalaileh. \\ This is an open access article licensed under the Creative Commons \\ Attribution-NonCommercial-NoDerivs License \\ (http://creativecommons.org/licenses/by-nc-nd/3.0/).
}

\title{
The American- Turkish Relationship and Its Effect on the Syrian Crisis
}

\author{
Dr. Ra'ad A. Al-Awamleh \\ Assistant Professor, \\ AL- Balqa' Applied University \\ Dr. Yusra S. Alkhalaileh \\ Lecturer \\ Hashemite University
}

Doi: $10.36941 / \mathrm{mjss}-2019-0073$

\begin{abstract}
The Syrian crises have been an issue of international concern since 2011. The conflict, which pitched the Bashar al-Assad led Baath regime against domestic and international oppositions, has led to a chain of events which have cascaded into social, economic, and humanitarian crisis in Turkey which shares boundary with Syria. With the toll of dead civilians and combatants exceeding a half million and displaced refugees reaching more than five million people especially women and children, the attention of the US has been drawn to the region. The need for the US and Turkey to work together is traditional. However, differing perspectives have led to different priorities. This paper examines the Turkish focus on Syria as a foreign policy dilemma and American focus on the terrorism and the humanitarian aspect of the crisis and how this have affected the crisis in Syria.
\end{abstract}

Keywords: Crisis, American-Turkish, Terrorism, Regime, Conflicts

\section{Introduction}

One of the blights on modern political and civil life is the ongoing civil crisis in Syria. What started as a skirmish in 2011 and reported to be a spill - over effect of the Iraqi war and the Arab Spring has waged on for more than seven years (Stein 2017). The crisis, fought between the forces of Bashar al-Assad and his Baath Party supporters on one side and various combinations of Syrian opposition and their foreign allies on the other side, have gradually morphed into a geopolitical and indeed global crisis. According to the United Nations High Commissioner for Refugees (UNHCR) in 2017, the crisis has led to the death of around half a million combatant and civilian and more than five million displaced refugees (Global 2017). The crisis has drawn the attention of various countries including Turkey and the USA. The 2011 supply of arms to forces, opposing the Assad regime, heralded the entry of Turkey into the crisis. The entry of the US into the crisis hinged on its status as a superpower, the need to combat international terrorism and its Middle Eastern interests. Over the years, the ever shifting dimensions of the crisis, for example the emergence of ISIS, have changed the nature of participation of the countries especially the US and members of the NATO bloc who want to combat terrorism. While America and Turkey have played significant roles in ensuring Middle - Eastern peace, there remain inherent conflicts on how the Syrian crisis should be approached. The Syrian crisis has the potential of jeopardizing for a long period the relationship between Turkey and the USA.

This paper is an attempt to provide an overview of the American - Turkish relationship from 
the perspective of the ongoing Syrian crisis. The aims of the US - Turkey efforts at mitigating the crisis, the common points, and the points of difference will be reviewed. The individual policies of US and Turkey on Syria will be evaluated, and the consequences of policy disagreements among the two countries will also be examined. A section will also provide certain policy recommendations that could potentially stem the tide of the conflict through a more coherent and convergent working relationship between the US and Turkey.

\section{Statement of Problem and Research Questions}

The US and Turkey have played critical roles in various aspects of the Syria crisis. While there have been differences in perspectives, the conventional view is that a comprehensive resolution of the conflict cannot be achieved without the cooperation and support of the two countries (Albright, Hadley et al. 2012, Peerzada 2015, Stein 2017). However, both countries are continuously approaching the crisis from different vantage points, and this has led to the dearth of decisive actions that could shorten the conflict and mitigate its effects. The consequence of this differential is evident in the mounting human, financial, social, and diplomatic costs of the crisis. This paper therefore seeks to examine the effects of the American- Turkish relationship on the Syrian crisis, and also to propose a set of policy recommendations that could help foster better relations between the two countries and bring the conflict to a close. The following questions will be explored;

1. What is the nature of the relationship between Turkey and Syria, US and Syria and the US and Turkey?

2. In what ways have the American-Turkey relationship affected the Syrian crisis?

3. What policy recommendations would strengthen the role of the Turkish-American relationship in bringing the Syrian crisis to an end?

\section{Research Objectives and Methodology}

The general objective of this paper is to examine the American- Turkish relationship and its effects on the Syrian crisis, while the specific objectives are to;

1. Examine the nature of the relationship between Turkey and Syria, US and Syria and the US and Turkey.

2. Identify the ways in which the American-Turkey relationship has affected the Syrian crisis.

3. Proffer policy recommendations that would strengthen the role of the Turkish- American relationship in ending the Syrian crisis.

This paper utilized a desk research as a methodology and in garnering information. Desk research defined by Jackson (1994, p. 21) as "the process of accessing published secondary data". It mainly relies on identifying, analyzing, synthesizing and critically examining the available data from multiple sources such as reviews of literature and published reports and statistics. This involves reviewing the relevant literature on the crisis and the role-played by the US and Turkey. This study undertook searching and exploration of the development of Syrian crisis and its implications of using data from multiple sources to examine the issues of how the United States and Turkey see the Syrian crisis and their priorities in dealing with it and its consequences.

\section{The Syrian Crisis}

What in contemporary history has come to be termed the Syrian crisis is best described as an amalgamation of strategic struggles for power in Syria as the physical domain and the Middle East, as the wider domain, were affected by internal and external factors based on the lines of ethnicity (Abramowitz and Edelman 2013). According to Peerzada (2015), the Syrian crisis had by 2015 led to the displacement of more than a million people and the death of a more than a quarter - million people (Peerzada 2015). The crisis has over the years taken on the dimensions of a global security threat and no longer just a domestic issue or another Middle Eastern regional event. It has within a short time enlarged in scope and took on the patterns of geopolitical events morphing into full scale international conflicts (like the First and Second World Wars). Abramowitz and Edelman 
(2013) expressed that 'the Syrian crisis have morphed from a domestic issue to a proxy war entailing a strategic struggle for power and influence in the Middle East and occurring in a context of international events and internal and external factors. Another researcher stated that with the emergence of public uprising, followed by the civil war and then regional powers, the Syrian crisis became a proxy war (Ekşi 2017). That the conflicts have assumed a course that is violent, complex, and uncertain can be traced to these internal and external factors. Statistics have shown that as a result of the conflict, an approximate number of 250,000 people have been killed, and 13.5 million people in Syria are in urgent need of humanitarian assistance (Yazgan, Utku et al. 2015, Initiative 2017). Due to the deteriorating infrastructure in Syria, there is an alarming rate of poverty originating from poor water supply system which affected agricultural activities, resulting in the migration of a lot of people to cities attributed to the drought that took place between 2007 to 2010 (Haddad 2011, Hinnebusch 2012). Between 2005 - 2011, Syria experienced an increase in poverty by $10 \%$ (Haddad 2011).

The conflict have come to be factionalized among those who want to topple the Assad regime and those who consider toppling the regime to be insignificant and potentially laden with negative consequences in the long run (Phillips 2012, D'Alema 2017). The Assad regime is increasingly been supported by Iran and Russia, and this has caused fractures in the process of negotiating an end to the processes. Albright (2013) expressed that the Syrian crisis have the potential of leading to a show off between the US and Russia threatening to bring back the spectre of the Cold War. The emergence of the extremist terrorist organization, ISIS, have added another dimension to the crisis, and this have made the situation more complex precipitating the increased attention given to the crisis by the US and EU countries. Domestically, Syrians are divided in terms of perspectives about the conflict. While the actions of the Assad regime have served to catalyse the crisis, civil society in Syria is divided along the lines of those who want the regime toppled and those who support the regime (Stein 2017). The crisis is also presented as a strategic regional competition or conflict between the Sunni and the Shia blocks. There is also a division which was manifested among the Middle Eastern countries. On one side are the Anti - Western countries of Syria and Iran, while on the other side are the Pro - Western countries of Jordan, Saudi Arabia, and Turkey.

\section{Relations between America and Turkey}

Diplomatic relations between Turkey and the US go back since the years of the Cold War. As noted by Baker (2017), 'the US have a strategic interest in Turkey which was initially based on the need for Turkey to serve as a bulwark against the expansion of communism into Europe' (p.89-96). While the US - Turkey relationship was strong during the war, there have been instances of conflict between the two countries especially the delicate issue of internal governance in Cyprus (Kissinger 2002). The 'containment area against communism' role played by Turkey became downplayed after the end of the Cold War. An imperative point to note is that while Turkey does not play any significant role in securing their national interests, the US and the countries of Western Europe believe Turkey is an invaluable ally to have in the Middle East (Albright, Hadley et al. 2012, Thomas and Zanotti 2018).

\section{Turkey and the Syrian Crisis: A Foreign Policy Situation}

Historically, Turkey and Syria have in the past mutual interests in securing the stability of the Middle East. According to Flanagan and Brannen (2008), the mutual interests of Turkey and Syria revolve around energy, diplomatic relations with the West, and combating extremism and terrorism (Flanagan and Brannen 2008). However over the years, certain events have casted a pale on relations between the two countries. This include historical territorial disputes (for example, the Hatay dispute of 1939), Turkey's pro - West and pro - Israel stance, the Cold War (in which the two countries supported the West and the Russian blocs, respectively) and the perennial conflict over the water resources of the Tigris and the Euphrates on which both countries stake historical claims (Ifantis 2013).

According to Szymanksi (2017), Turkish perspectives and actions in relation to the Syrian 
crisis have been shaped by a number of factors. Some of these factors bore the distinction of shaping Turkish foreign policy in Nigeria. Such factors include the geostrategic location of Turkey, the geopolitical situation of the Middle East, historical factors, cultural - ideological factors, state capacities, and current affairs regarding foreign and domestic policy. The geostrategic location of Turkey is one of the factors that predisposed Turkey as a major player in the crisis (Aras and Köni 2002). Aykan (1999) stressed that Turkey had historically acted as the gateway to Europe for the Arabian countries, including Syria, and this has political and economic dimensions of importance. Turkey's gateway status had also posed a bind when it comes to the questions of regional identity and external perception both by the Arabs and the Europeans.

The Syrian crisis had strained relations between the country and Turkey. It has been asserted that the bilateral relations between Turkey and Syria crumbled after the Arab spring and the escalation of conflict in Syria (Aras and Köni 2002). Hence, this led to the adoption of various measures by the Turkish state in curbing the excesses of her neighbour. Another key factor in the changed relationship between the two countries is the role played by an ever changing network of political and foreign policy determinants. Szymanski (2017) noted that it was patently difficult for Turkey to implement its 'zero problems with neighbours' themed foreign policy program while relying on the soft power tools of diplomacy alone (Szymański 2018). For the Turkish, the violence in Syria constitute the role of the security factor in foreign policy, and this later informed actions towards Syria that has come to shape ongoing events in the crisis and the relations between Turkey and other countries especially the United States and Russia.

(Abramowitz and Edelman, 2013) have expressed that 'the Syrian crisis represents a major foreign policy challenge to the nation of Turkey; a foreign policy challenge with immense consequences for the national security of the country' (p.6). According to the authors, Turkey's concern is reflected in two major dimensions. First is the issue of the Kurds which the Turkish government have denied autonomy and territory for a long period. It is feared by the Turkish government that if the agitation of Syrian Kurds for territory is met, a regional crisis will ensue with Kurds in Turkey making similar demands (Kaya and Whiting 2017). The other concern for the Turkish is the issue of refugees displaced by the violence in Syria. The influx of refugees has severely strained political, social, and economic life in Turkey (Bajalan, Çalislar et al. 2013). Turkey's stance on Syria evolved over time and tipped when Turkey started granting asylum to members of Syria's political opposition parties and supplying arms to opposing military forces. Ifantis (2013) speculated that Turkey's opposition of the Assad regime escalated when the regime's continuing violence led to the death of about ten thousand Syrians (Ifantis 2013). This episode led to the Turkish government suspending diplomatic relations with Syria and enacting sanctions.

The situation in Syria has continually shaped Turkish foreign policy. In fact, the present Turkish government have the strong opinion that Turkey's foreign policy in the following years should be shaped by the events emerging from Syria. Christopher (2012) summarized Turkey's Policy against Syria to include "trying to persuade Assad to reform; cutting diplomatic ties; supporting regional and international political solutions; and supporting and aiding Syria's political and armed opposition. While advocating a fifth stage - direct military intervention against the Assad regime, such as a no-fly zone or humanitarian corridor - Turkey is unwilling to act unilaterally" (p.1). Early in the crisis, Turkey made certain decisions which had catastrophic consequences because of intelligence failure and wrong assumptions. Stein (2017) suggested that the Turkish government assumed wrongly that the US and Europe have a necessity to topple the Assad regime; it also assumed wrongly that the Assad regime will respond to military threats and remain in power for a shorter time. Turkey also miscalculated how the Sunni and Shiite alliances will play out. As events turned out, the initial policies of Turkey that would have toppled the Assad regime were diplomatically foiled by the Iran- Shiite alliance and the Saudi Arabia- Sunni alliance.

\section{America and the Syrian Crisis: Combatting International Terrorism}

The mainstream American perspective about participation in the Syrian crisis is that it provides an opportunity to stem the spread of terrorism. Any solution not seen in terms of combating terrorism does not have real support in America. This has caused a rift with America's Middle Eastern 
partners, especially Turkey. Peerzada (2015) asserted that the United States developed a policy framework towards Syria in the 1980's. The American policy is built around peace for Israel and an end to the support that Palestinian extremists and the terrorist group Hezbollah enjoy from Syria. This policy frame still guides US actions in the crisis. According to Abramowitz and Edelman (2013), the US have a Middle Eastern policy of containing the budding regional hegemony ambition nursed by Iran, lessening the tide of political Islam, eradicating and preventing the use of chemical and biological weapons, securing the region so as to deny terrorists safe haven, and reduce the security threat that the Middle Eastern countries have traditionally posed to the state of Israel.

Peerzada (2015) pointed out that the American government does not view the Syrian crisis as a direct threat to the country's security, rather it is perceived as a humanitarian crisis (Peerzada 2015). However, Albright (2013) opined 'that while American interest in Syria is seen as humanitarian, it has the potential secondary consequences of maiming the American ambition of destroying weapons of mass destruction (WMDs), stemming the tide of state- sponsored terrorism and fostering the recognition of fundamental human rights and economic development of the area' (p.41). To the Americans, these aims are not necessarily attained through military intervention. Basically, the involvement of the US has been limited to humanitarian support and coordination, combating terrorism, and containing the influence of Syrian extremist groups. Such relatively passive involvement, which significantly pales in comparison to US involvement in Korea and Bosnia, requires the tactical support and assistance of regional powers like Turkey and other global powers especially Russia which ironically supports the Assad regime. It has been suggested, the geopolitical realities of the conflict and Russia's implicit support of the Assad regime posits Turkey and the US as two principal actors on whose actions the outcome of the conflict depends (Aras and Köni 2002).

\section{American - Turkish Relationship and the Syrian Crisis: The Chain of Effects}

The United States of America and Turkey both have interests purported to be of national security in Syria and the Syrian crisis (Kanat, 2015). According to Peerzada (2015), a key dimension of the international nature of the Syrian crisis, especially as it affects the USA and Turkey, is that both countries have a number of convergent and divergent interests. From the point of policy divergence, the interests of Turkey and the US in Syria are not the same. While both countries believe that the Assad regime should be toppled, there is a fundamental disagreement over which aspects of the crisis to focus on and which opposition element or combination of elements should be supported. In essence, there is a convergence over the major aims of managing the Syrian crisis but a divergence on policies and methods (Ifantis 2013). Traditionally, Turkey alongside Saudi Arabia and Jordan is a predominant country in the Pro- Western bloc among the nations of the Middle East, and it has always sought US support in maintaining peace and stability in the region (Atmaca 2017).

However, Turkey considered the relationship with the US strained for some reasons. For example, the Turkish government is sored because of the unwillingness of the US to directly commit its resources to toppling the Assad regime. One of the conventional viewpoints on why the Syrian crisis has continually escalated with the attendant consequences of death and destruction is because the US and Turkey have divergent interests and conflicting priorities (Bajalan, Çalislar et al. 2013). Kanat (2015) suggested that 'from the perspective of the Turkish government, the policy adopted by the Department of State as reflecting the official policy of the United States' government is ambiguous with no clearly spelt out program or initiatives' (p.10). Peerzada (2015) also speculated that the 'ISIS first' approach adopted by the US is sequentially at odds with the 'toppling Assad's regime' foreign policy goal adopted by Turkey. The interest of Turkey in Syria conflicts with those of the United States. Firstly, Turkey has regional aspirations in the Middle East and the Black Sea area. These are aspirations which are at odds with the position of the United State foreign policy (Albright, 2013; Abramowitz \& Edelman, 2013). Critics such as the eminent scholar Fatiullah Gulen who have criticized Turkey's hegemonic aspirations and pointed out supporting actions such as Turkey's quest to force policies on Syria during the revolutionary uprising of 2001 have been continually attacked by the government and Gulen especially self-exiled himself to the US. Other 
hegemonic forays of Turkey that have made the US cautious in handling the Syrian crisis include Turkey's involvement in the Caucasus and the Balkans. Other interests of Turkey relate to the Kurdish issue and the influx of refugees.

The influx of refugees represents the Humanitarian dimensions of the Syrian crisis which deeply affects the Turkish state. The civil war in Syria had women and children as the main casualties and the number of displaced persons is increasing geometrically every year. As at 2015, more than seven million Syrians have been displaced with Turkey alone accommodating around two million. This has placed a heavy burden on the Syrian government (Yazgan, Utku et al. 2015, Global 2017). Another issue of particular interest to Turkey is the Kurdish question. The Turkish government and parliament fear that an escalating civil war in Syria has the potential of serving as a pretext for the Kurds to demand autonomous rule and sovereign. This Kurdish issue have important territorial and defence ramifications for Turkey (Kaya and Whiting 2017). According to Zanotti and Thomas (2018), 'the Kurds, an ethnic group spread out in Iraq, Turkey, Iran, Syria, have long aspired to have their own state and the Turkish Security mind-set reflects a deep-seated fear of the state's territorial dismantlement if the Kurds have their way' (p.13).

The American government have touted a policy line which seem to assert that Turkey have an overestimated view of her influence in the region in general and in Syria in particular. Peerzada (2015) opined that 'Turkey did not have the diplomatic or military capability to play the role of rule maker in the region' (p.14). Ertugrul (2012) suggested that there are informational and intelligence gaps and oversights in the Turkish handling of the Syrian situation. This is reflected in the country's dearth of foreign policy specialists and intelligence operators who are familiar and knowledgeable about the Syrian situation. Conventional thought in the American government and foreign policy circles shows that Turkey did not maximize the strategic options available during the early stages of the Syrian crisis. Ifantis (2013) outlined three different options available to Turkey at the start of the crisis. Ifantis claimed that Turkey could have followed the course of supporting either the civilian or military opposition groups while creating the path for peaceful conflict resolution and providing military support concurrently. NATO could also have brokered a NATO backed military support for the military groups opposed to Assad. That Turkey did not develop a coherent policy exploring these options early in the crisis and castigating the United States for not taking these steps later on is seen as hypocritical on the part of the Turkish government and have created rifts between the two countries. Primarily, America has differing views with Turkey on the Kurdish question and Turkey's overall role in the Syrian crisis.

The differences in perspectives between the two countries have led to different priorities and policy responses. While the Assad regime has committed grave human rights related crimes, the American government does not have toppling regime as a priority. The relationship between the US and Turkey have naturally taken on the nature of alliance and was relatively marred only by the focus of the US on international terrorism and their state sponsors such as Syria and Iran. This move have relegated to the back, the concerns of the Turkish state which according to Stein (2017) are internal insurgency, sabotage and the Kurdish question. The rift in US - Turkey relationship has led to strategic and tactical confusion in managing the Syrian conflict. This has only played into the hands of Assad who clearly benefits from the delayed decisive action that could have resulted from a coherent policy. The delay in designing and implementing US - Turkey policies is particularly ominous later due to the fact that Turkey share boundaries with Syria and Iraq (Bajalan, Çalislar et al. 2013).

This confusion is more manifest in the use of military intervention. The US stance is against the use of the military, and this is an outworking of the ISIS first and Iran-first approaches adopted by the government. The non-usage of military intervention have also been interpreted by Turkey and other opposition parties as ambiguousness on the part of the US (Thomas and Zanotti 2018). This, coupled with American focus on ISIS, have been seen as the reason for continuance of the conflict because the commitment of America's military resources against ISIS is believed to relieve Assad of the need to focus his military on the terror group thus taking military pressure off the regime. Another perception is that the US is playing out a Middle East exit strategy. The strain in Turkish - American relationship set back the crisis management effort when in 2014; Turkey refused to sign the 'Declaration of Jeddah'. The declaration, based on an earlier summit staged to 
form an Anti-ISIS coalition to be led by United States, was actually attended by Turkey. However, Turkey pulled out of the coalition citing strategic reasons. Thomas and Zanotti (2018) suggested that Turkey pulled out of the coalition because of its concerns that membership mark it as a more proximate target for ISIS because of the border it shares with Syria. Turkey also signalled disapproval of the coalition by denying the coalition access and use of the Incirlik airbase for their operations. This is one of the pernicious effects of the strategic and tactical policy rift between the US and Turkey and how it affects the ongoing crisis in Syria.

It is important to note that the ongoing Syrian conflict and the tension it has evoked between the USA and Turkey have impacts and implications on the domestic politics of the two countries (Barkey 2016). It is a conventionally accepted viewpoint that if a workable consensus on the Syrian issue remain absent because of American and Turkish actions, the American congress might resort to the passing of bills that are largely unfavourable to Turkey. On the converse, as noted by Baker (2017), actions taken by the United States in relation to the Syrian crisis will be exploited as explosive domestic issues by opposition parties in Turkey especially when such actions are largely inconsistent with Turkey's stance on the crisis. It can be inferred that solving the Syrian crisis problem from the perspective of both countries require diplomatic feints and counter-feints in which the secondary effects of decisions and their impact on domestic policies must be weighed (Barkey 2016, Atmaca 2017).

Other effects of the strained alliance between the US and Turkey include the opposition of Turkey to the direct aid America is giving opposition groups in Syria and the refusal of America to extradite the cleric Fatiullah Gulen on the grounds that there are no legal basis for extradition (Peerzada 2015, Stein 2017). Another solution that have been jointly explored by the US and Turkey relates to the establishment of safe corridors in Syria. This option bogged down due to realization that claiming territory for safe corridor purposes might be misconstrued by Assad to be an act of war, and this could foil the peace process.

\section{The Way Forward}

Mitigating the Syrian crisis by the joint actions of the US and Turkey is one of the most viable path to bringing stability to the region. This can, however, be achieved if certain conditions are put in place. There is a need for more proactive agreements between the US and Turkey on what the modus operandi of managing aspects of the Syrian crisis in which both countries have interests should be. Ensuring a peaceful resolution of the conflict and a successful post-conflict restoration program will depend on how well the two countries converge on major policy and tactical points. It is imperative to note that while the Syrian civil war have morphed into global crisis with attendant effects whose secondary consequences will only be known in the future, any solution must be based on a consideration of the national interests of Syria's neighbour, Turkey. As such, for proposed solutions to be acceptable, workable and sustained, the Kurdish question and the Humanitarian dimensions of the crisis must be managed in a way acceptable to Turkey. Any program or initiative that does not consider these variables will only degenerate into further regional crises. Of course, the probability that workable solutions that would be agreeable to all parties involved in the conflict including Turkey and the US is not high. Nevertheless, both countries should make judicious use of concessions and focus on the long-term impacts of decisions, as this is the only bulwark against further conflicts in the area.

The United States must come to the realization that its primary objectives of combating terrorism, stabilizing the Middle East, and exiting from Iraq cannot be achieved in an effective manner without the strategic and tactic support of Turkey. Turkey must also come to the realization that its geopolitical goals and the proposed humanitarian crisis management solutions cannot be achieved outside the context of US involvement. The US will find fighting on the multiple fronts of combating ISIS, managing the Syria crisis, tentatively disposing the Assad regime (if it becomes a feasible goal for the US), and stabilizing Iraq to be easier to manage with Turkey as a principal ally. The stance that Turkey has taken steps which are conflicting with long-term geopolitical goals should be revised. A confrontational perspective will only undermine the working relationship between the two countries that is necessary if the Syrian conflict will be brought to an end in the 
nearest future.

Turkey's actions can only be understood from the perspective of her own interests. According to Szymanski (2017), 'Turkey's relatively neutral position towards regional conflicts was transformed into a kind of sectarian policy and support for one side in inter- and intrastate conflicts because of geopolitical realities' (p.71) (Szymański 2018). The role of the Arab Spring in creating grave problems for the implementation of Turkish foreign policy should be acknowledged. In addition, American-Turkish tensions diffused towards solving the Syrian crisis is the foreign policy dilemma in which Turkey found herself. İçduygu (2015) contended that Turkey had to make a choice as to whether or not to continue helping Middle Eastern governments economically and politically as stipulated in its strategic depth doctrine or whether to support the citizens of those countries in their protests and clamour for democracy (democracy promotion is a cardinal principle of Turkish foreign policy) (İçduygu 2015). Turkey is indeed walking on a diplomatic tight rope, and this should be acknowledged by the United States.

Lastly, the long-term solution to the crisis of the Middle East is the introduction and widespread acceptance of democratic principles in Middle East governments. Turkey, with her own well developed and entrenched democratic system, have the potential of taking a lead in an initiative like this. However, such initiative also depends on the cooperation and support of a country like the United States. In this, the two countries must create actionable programs and jointly design systems to implement them. Two researchers have expressed that the long term security interests of Middle Eastern countries are best served within the context of democracy, society-wide enfranchisement, and sustained economic development (Aras and Köni 2002, Szymański 2018).

\section{Conclusions}

Evidence suggested that while there are areas of convergence between the US and Turkey, there are more aspects in which there is a divergence in the perspective and actions of the two countries and this is continually having negative effects on the conflict management efforts. Turkey resents the fact that the US and NATO have refused her entreaties for military aid in toppling Assad, while the US and NATO are sore at Turkey for not committing to the anti- ISIS coalition. It is imperative to note that the dithering in action occasioned by flawed Turkish-American relations will continue to protract the human, diplomatic and financial costs borne by Turkey, and this spell disaster for the region and greater global dangers. Without a clear program of cooperation, chaos, violence, carnage, humanitarian crisis and insecurity will continue to plague the Middle East. It is thus imperative for stability that Turkey and the US should cooperate.

\section{References}

Abramowitz, M. I. and E. S. Edelman (2013). "US-Turkish Cooperation toward a Post-Assad Syria." Bipartisan Policy Center: 9.

Albright, M. K., S. J. Hadley and S. F. S. A. Cook (2012). US-Turkey Relations: A New Partnership, Council on Foreign Relations.

Aras, B. and H. Köni (2002). "Turkish-Syrian relations revisited." Arab Studies Quarterly: 47-60.

Atmaca, A. Ö. (2017). Turkey-US Relations (2009-2016): A troubled partnership in a troubled world? Turkish Foreign Policy, Springer: 63-82.

Bajalan, D. R., O. Çalislar, F. Keyman, U. Özkirimli, C. Çandar, M. M. Gunter, K. B. Kanat, H. Pope, G.

Bacik and B. B. Coskun (2013). Understanding Turkey's Kurdish Question, Lexington Books.

Baker, S. (2017). Syria: Power and Priorities. Council on Foreign Relations, no 122. 89- 96.

Barkey, H. J. (2016). "Syria's Dark shadow over US-Turkey relations." Turkish Policy Quarterly 14(4): 25-36.

D'Alema, F. (2017). The Evolution of Turkey's Syria Policy, Istituto Affari Internazionali.

Ekşi, M. (2017). "The Syria Crisis As a Proxy War and the Return of the Realist Great Power Politics." Uluslararası Kriz ve Siyaset Araştırmaları Dergisi 1(2): 106-129.

Flanagan, S. J. and S. Brannen (2008). Turkey's shifting dynamics: implications for US-Turkey relations, CSIS.

Global, U. (2017). "Trends: Forced Displacement in 2016." Geneva, Switzerland: UNHCR.[Google Scholar].

Haddad, B. (2011). "The political economy of Syria: realities and challenges." Middle East Policy 18(2): 46.

Hinnebusch, R. (2012). "Syria: from 'authoritarian upgrading'to revolution?" International Affairs 88(1): 95-113. 
İçduygu, A. (2015). "Syrian refugees in Turkey: The long road ahead." Washington, DC: Migration Policy Institute.

Ifantis, K. (2013). "The US and Turkey in the fog of regional uncertainty."

Initiative, E. S. (2017). "The 2015 Refugee Crisis through Statistics."

Jackson, P. (1994). Desk Research.Kogan Page: 21.

Kaya, Z. and M. Whiting (2017). "Sowing division: Kurds in the Syrian war." Middle East Policy 24(1): 79-91.

Kissinger, H. (2002). Does America need a foreign policy?: Toward a diplomacy for the 21st century, Simon and Schuster

Peerzada, T. A. (2015). "US-Turkey relationship and Syrian crisis." Alternatives: Turkish Journal of International Relations 14(4): 11-19.

Phillips, C. (2012). Into the quagmire: Turkey's frustrated Syria policy, Chatham House London.

Stein, A. (2017). Reconciling US-Turkish Interests in Northern Syria, Council on Foreign Relations.

Szymański, A. (2018). "Turkish Policy Towards war in syria." TEKA of Political Science and International Relations 12(1): 63.

Thomas, C. and J. Zanotti (2018). Turkey: Background and US Relations, CRS Report, August.

Yazgan, P., D. E. Utku and I. Sirkeci (2015). "Syrian crisis and migration." Migration Letters 12(3): 181-192. 